\title{
Andrzej Raszkowski
}

Uniwersytet Ekonomiczny we Wrocławiu

e-mail: andrzej.raszkowski@ue.wroc.pl

\section{GMINA MIEJSKA PIECHOWICE W OCZACH MIESZKAŃCÓW - RAPORT Z BADAŃ \\ PIECHOWICE MUNICIPALITY IN THE EYES OF RESIDENTS - RESEARCH REPORT}

DOI: $10.15611 /$ pn.2017.490.09

Streszczenie: Niniejsze opracowanie powstało w oparciu o badania ankietowe, które przeprowadzone zostały na zlecenie Urzędu Miasta w Piechowicach w okresie wrzesień-listopad 2015 r. Wspomniany proces badawczy był jednym z etapów tworzenia nowej Strategii Rozwoju Gminy Miejskiej Piechowice na lata 2015-2026. Celem opracowania jest przedstawienie oraz ocena wybranych sfer funkcjonalnych Gminy Miejskiej Piechowice (środowisko geograficzne, gospodarka, infrastruktura techniczna, infrastruktura społeczna, zarządzanie miastem) w opinii mieszkańców. Przedstawione w artykule analizy oraz wnioski potwierdzają stosunkowo korzystne postrzeganie gminy przez wybranych członków społeczności lokalnej. Jednocześnie stanowią punkty wyjścia dla władz samorządowych oraz innych lokalnych środowisk do planowania projektów niwelujących dostrzeżone słabości.

Słowa kluczowe: rozwój lokalny, Piechowice, społeczność lokalna, raport badawczy, strategia rozwoju gminy.

Summary: The presented study was prepared based on survey studies ordered by the Municipal Office in Piechowice in the period September-November 2015. The aforementioned research process was one of the stages in developing the new Development Strategy of Piechowice Municipality for the years 2015-2026. The purpose of the study is to present and evaluate the selected functional spheres of Piechowice Municipality (geographic environment, economy, technical infrastructure, social infrastructure, city management) in the opinion of residents. The analyses and conclusions presented in the article confirm the relatively favourable perception of the municipality by the selected members of the local community. They also constitute the starting points for local authorities and other local environments to plan projects eliminating the perceived weaknesses.

Keywords: local development, Piechowice, local community, research report, development strategy of the municipality. 


\section{Wstęp}

Niniejsze opracowanie powstało na bazie raportu z badań opinii społeczności lokalnej na temat oceny ogólnego stanu oraz sfer funkcjonalnych Gminy Miejskiej Piechowice. Przesłanką powstania wspomnianego raportu było zaangażowanie i dbałość o jak najszersze uspołecznienie oraz partycypację społeczną w procesie powstawania strategii rozwoju Piechowic. Ponadto kompleksowy raport stanowi integralną część Strategii Rozwoju Gminy Miejskiej Piechowice na lata 2015-2026. Zebrane informacje, oprócz wspomagania procesu powstawania strategii gminy, są cennym źródłem wiedzy o preferencjach rozwojowych oraz ocenie stanu Piechowic w oczach ich mieszkańców.

Zawarte w raporcie wyniki badań oraz wnioski, z uwagi na ograniczony zasięg, stanowią materiał poglądowy, niemniej jednak wspierają procesy decyzyjne władz lokalnych oraz innych środowisk zaangażowanych w rozwój społeczno-ekonomiczny gminy, polegające na podejmowaniu działań stanowiących odpowiedź na sygnalizowane zapotrzebowanie społeczności. Ponadto wspomagać mogą ułożenie partnerskich relacji, konsensusu władz samorządowych z innymi aktorami lokalnej sceny, wpisując się tym samym w logikę efektywnego funkcjonowania strategii rozwoju lokalnego [Klasik 2002; Raszkowski 2014].

Celem niniejszego opracowania jest przedstawienie oraz ocena wybranych sfer funkcjonalnych Gminy Miejskiej Piechowice (środowisko geograficzne, gospodarka, infrastruktura techniczna, infrastruktura społeczna, zarządzanie miastem) w opinii społeczności lokalnej. Ponadto artykuł został wzbogacony o wnioski i rekomendacje.

\section{Metodyka badań}

Piechowice są gminą miejską w powiecie jeleniogórskim, która obejmuje swoim obszarem część Karkonoszy i Gór Izerskich oraz fragment Kotliny Jeleniogórskiej w województwie dolnośląskim. Oprócz Piechowic w skład powiatu jeleniogórskiego wchodzą następujące jednostki samorządu terytorialnego: Karpacz, Kowary, Szklarska Poręba (miasta) oraz Janowice Wielkie, Jeżów Sudecki, Mysłakowice, Podgórzyn, Stara Kamienica (gminy wiejskie).

Gmina położona jest na wysokości 360-480 m n.p.m., granica administracyjna sięga do wysokości 1509 m n.p.m., graniczy z gminami: Jelenia Góra, Stara Kamienica, Szklarska Poręba oraz z Republiką Czeską. Piechowice status miasta posiadają od 1967 r., jest on od początku konsekwentnie utrwalany w układzie urbanistycznym (m.in. poprzez budowę osiedli mieszkaniowych) i społecznym (sukcesywne odchodzenie od funkcji rolnej na rzecz funkcji przemysłowo-usługowej). Górna, centralna i dolna część miasta leżą wzdłuż rzeki Kamienna, która niejednokrotnie powodowała zniszczenia powodziowe, natomiast poszczególne osiedla rozciągają się wzdłuż potoków lub strumieni. Podgórskie i stosunkowo rozległe położenie przekłada się na utrudnienia komunikacyjne, warunkujące konieczność zapewnienia autobusowej 
komunikacji publicznej. Miasto leży przy trasie drogi krajowej nr 3, która przebiega na odcinku Świnoujście - Jakuszyce. Z drogą krajową krzyżuje się droga wojewódzka nr 366 z Piechowic do Kowar, stanowiąca zarazem reprezentacyjną ulicę miasta, Żymierskiego. Funkcję dróg zbiorczych pełnią również drogi powiatowe [Strategia Rozwoju... 2010].

Gmina zajmuje stosunkowo rozległy obszar, $43,22 \mathrm{~km}^{2}$, w odniesieniu do liczby ludności, według stanu na 31 grudnia 2015 r. Piechowice liczyły 6234 mieszkańców. Użytki rolne stanowią 16\%, a użytki leśne 71\% (w tym teren Karkonoskiego Parku Narodowego) powierzchni gminy. Z obserwacji ruchu ludności wynika, że w ostatnich latach liczba ludności utrzymuje się na stabilnym poziomie. Ogólna liczba zarejestrowanych bezrobotnych w Piechowicach wyniosła 192 osoby w 2015 r., liczba podmiotów gospodarczych wg REGON - 761 (w 2014 r.). Do atrakcji turystycznych Piechowic oprócz obiektów kultury zaliczyć można: Śnieżne Kotły, Wielki Szyszak, Wodospad Szklarki, Bobrowe Skały i Cichą Dolinę. Rozwinięta sieć szlaków pieszych i rowerowych w mieście i okolicy (prawie $100 \mathrm{~km}$ ) stwarza dobre warunki do uprawiania różnorodnych form turystyki przez cały rok [Raszkowski 2010, 2015; Strategia Rozwoju... 2010; Koncepcja Subregionalnego... 2008].

Badanie ankietowe przeprowadzone zostało na zlecenie Urzędu Miasta w Piechowicach w okresie wrzesień-listopad 2015 r. i objęło swoim zasięgiem, na zasadzie doboru losowego, 50 mieszkańców. Narzędzie badawcze stanowił kwestionariusz ankietowy, który udostępniony został w wersji papierowej w Urzędzie Miasta. W tym miejscu podkreślić należy profesjonalizm i zaangażowanie pracowników administracji samorządowej w procesie badawczym. Wspomniany proces był jednym z etapów tworzenia nowej Strategii Rozwoju Gminy Miejskiej Piechowice na lata 2015-2026. Zebrane informacje stanowią również kompendium wiedzy o preferencjach rozwojowych oraz ocenie stanu miasta w oczach mieszkańców.

Jeśli chodzi o strukturę respondentów, to większość stanowiły kobiety (62-38\%). Najliczniejsze przedziały wiekowe stanowiły osoby w wieku 26-35, 36-50, 51-67 lat (po 28\% badanych), najmniej liczny był przedział 18-25 (6\%). Najwięcej badanych mieszkańców miało wykształcenie średnie (42\%) oraz wyższe (42\%). W kontekście aktywności zawodowej, najliczniejszą grupę stanowili zatrudnieni u pracodawcy (58\%) oraz emeryci/renciści (18\%), najmniej licznie reprezentowani byli pracodawcy i bezrobotni. W odniesieniu do czasu zamieszkiwania w Piechowicach, najwięcej badanych osób osiedliło się w latach 1970-1984 oraz 1985-1999 (po 26\%), najmniej liczną grupę reprezentowały osoby zamieszkujące od lat 1945-1954.

\section{Wyniki oraz analiza badań ankietowych}

\section{1. Środowisko geograficzne}

W sferze środowiska geograficznego zdecydowanie najlepiej, z dużą przewagą nad pozostałymi elementami, ocenione zostało położenie gminy ( $90 \%$ pozytyw- 
nych wskazań, tj. suma odpowiedzi „dobrze” i „bardzo dobrze”). Można założyć, że mieszkańcy Piechowic doceniają i liczą na swoistą rentę położenia, wynikającą z potencjału Karkonoszy, bliskości Republiki Czeskiej czy też funkcjonowania Aglomeracji Jeleniogórskiej. Jest to wskazanie o tyle pozytywne, co zastanawiające zarazem, ponieważ część mieszkańców powiatu jeleniogórskiego swoje położenie postrzega jako peryferyjne i utrudniające działania rozwojowe, z wyjątkiem sektora turystycznego. Dobrze wypadły również walory turystyczne gminy, z 66\% pozytywnych wskazań, oraz stosunkowo korzystnie ocena stanu środowiska naturalnego (46\% pozytywnych opinii). Zdecydowanie najmniej korzystnie w obszarze środowiska geograficznego wypadły czystość i porządek ocenione negatywnie (tj. suma odpowiedzi „źle” i „,bardzo źle”) przez $40 \%$ respondentów, przy $22 \%$ pozytywnych wskazań.

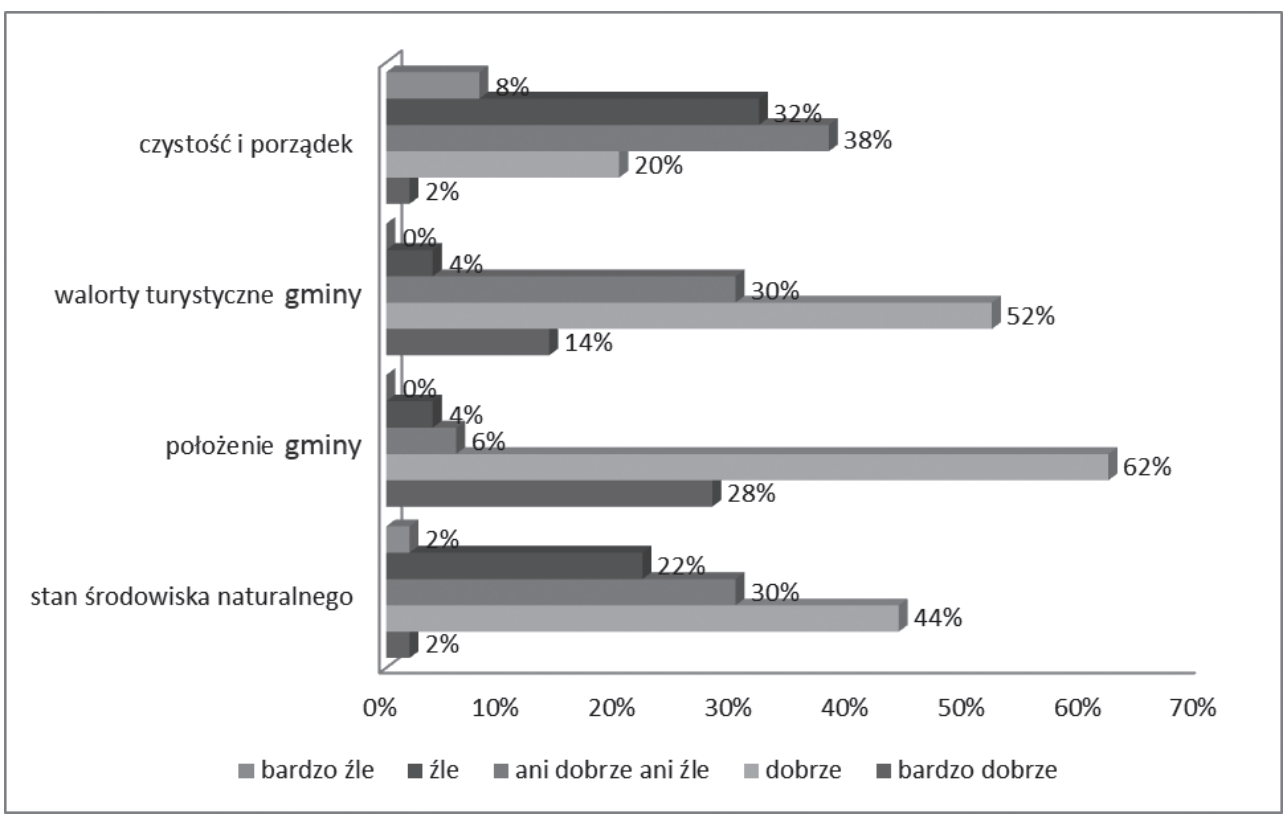

Rys. 1. Środowisko geograficzne - ocena sfery funkcjonalnej

Źródło: opracowanie własne na podstawie badań ankietowych.

\subsection{Gospodarka}

W ocenie elementów gospodarczych najkorzystniej postrzegana jest możliwość zrobienia zakupów, z $82 \%$ pozytywnych opinii. W tym miejscu należy dodać, że ten element jako jedyny ze wszystkich branych pod uwagę we wszystkich badanych sferach nie ma ani jednego negatywnego wskazania. Oczekiwania społeczności lokalnej wydają się więc zaspokojone w tym zakresie. Dobrze postrzegana jest również 
możliwość skorzystania z potrzebnych usług $\mathrm{w}$ gminie (46\% pozytywnych opinii). Największych problemów w obszarze gospodarki mieszkańcy upatrują w trudnościach związanych ze znalezieniem atrakcyjnej pracy oraz poziomie bezrobocia w gminie, odpowiednio 68 i 56\% negatywnych wskazań. Ponadto przewagę negatywnych nad pozytywnymi opiniami ma również możliwość otwarcia i prowadzenia działalności gospodarczej.

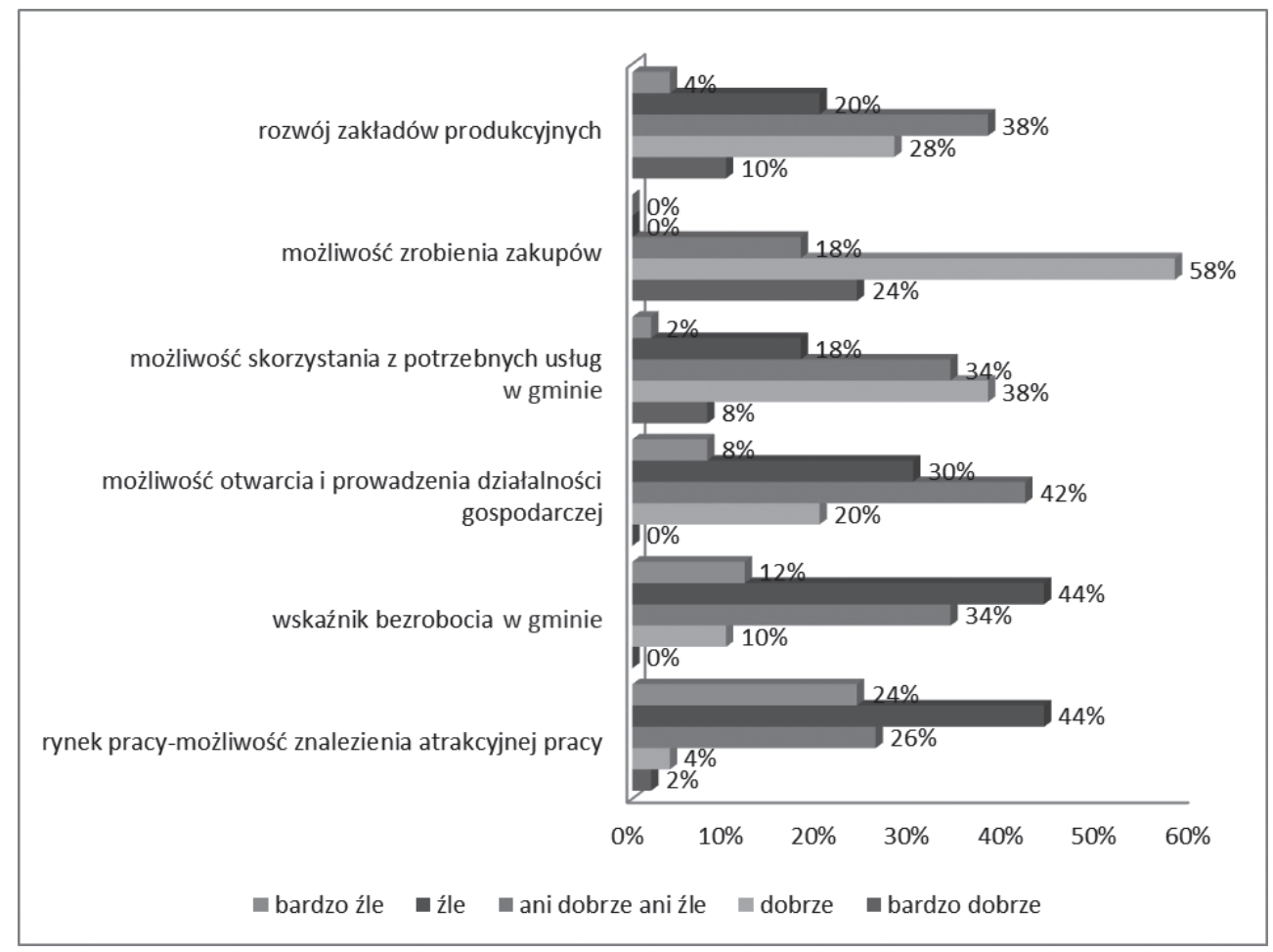

Rys. 2. Gospodarka - ocena sfery funkcjonalnej

Źródło: opracowanie własne na podstawie badań ankietowych.

\subsection{Infrastruktura techniczna}

Najsilniejszym punktem infrastruktury technicznej w oczach mieszkańców jest dostępność Internetu, z 54\% pozytywnych wskazań. Jest to istotna informacja z punktu widzenia potencjału rozwojowego gminy oraz właściwy krok w budowaniu społeczeństwa cyfrowego. Przewagę pozytywnych nad negatywnymi opiniami ma również dostępność komunikacji publicznej. Pozostałe elementy obszaru infrastruktury technicznej (stan gospodarki komunalnej, zasoby mieszkaniowe oraz jakość dróg i chodników) mają przewagę negatywnych wskazań. W tym gronie najgorzej wypadają zasoby mieszkaniowe (58\% negatywnych opinii wobec $18 \%$ pozytywnych). 
Powyższe wyniki, które są czytelnym sygnałem, powinny skłonić wszystkie środowiska odpowiedzialne za rozwój gminy do intensyfikacji działań mających na celu rozwój wybranych elementów infrastruktury technicznej.

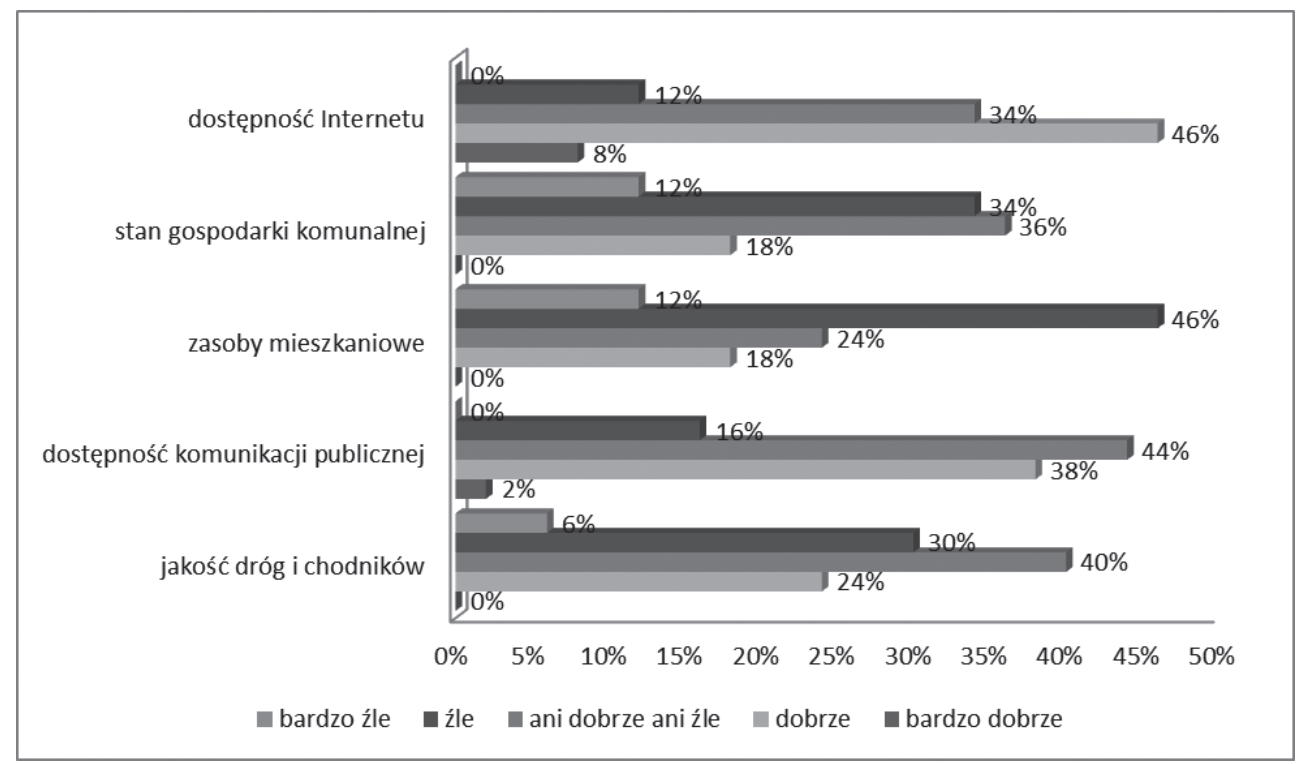

Rys. 3. Infrastruktura techniczna - ocena sfery funkcjonalnej

Źródło: opracowanie własne na podstawie badań ankietowych.

\subsection{Infrastruktura społeczna}

Szeroko rozumiana infrastruktura społeczna w nowej perspektywie finansowej Unii Europejskiej (2014-2020) zajmuje specjalne miejsce. Wiele projektów, współfinansowanych ze środków europejskich, ukierunkowanych jest i będzie na działania w tej sferze funkcjonowania samorządów. W świetle tych założeń, oceny obszaru społecznego w Piechowicach są szczególnie ważne. Najlepiej ocenione zostały możliwości kształcenia dzieci i młodzieży, dostęp do usług medycznych oraz wsparcie w zakresie pomocy społecznej, odpowiednio 52, 52 i 44\% pozytywnych opinii. Szczególnie cenna jest mocna pozycja możliwości edukacyjnych osób młodych. Na drugim biegunie znalazły się możliwość podnoszenia i zmiany kwalifikacji przez dorosłych, inicjatywy społeczne mieszkańców (w tym zgłaszane przez organizacje pozarządowe), status materialnych mieszkańców gminy, otrzymując odpowiednio 58,42 oraz $32 \%$ negatywnych wskazań respondentów. 


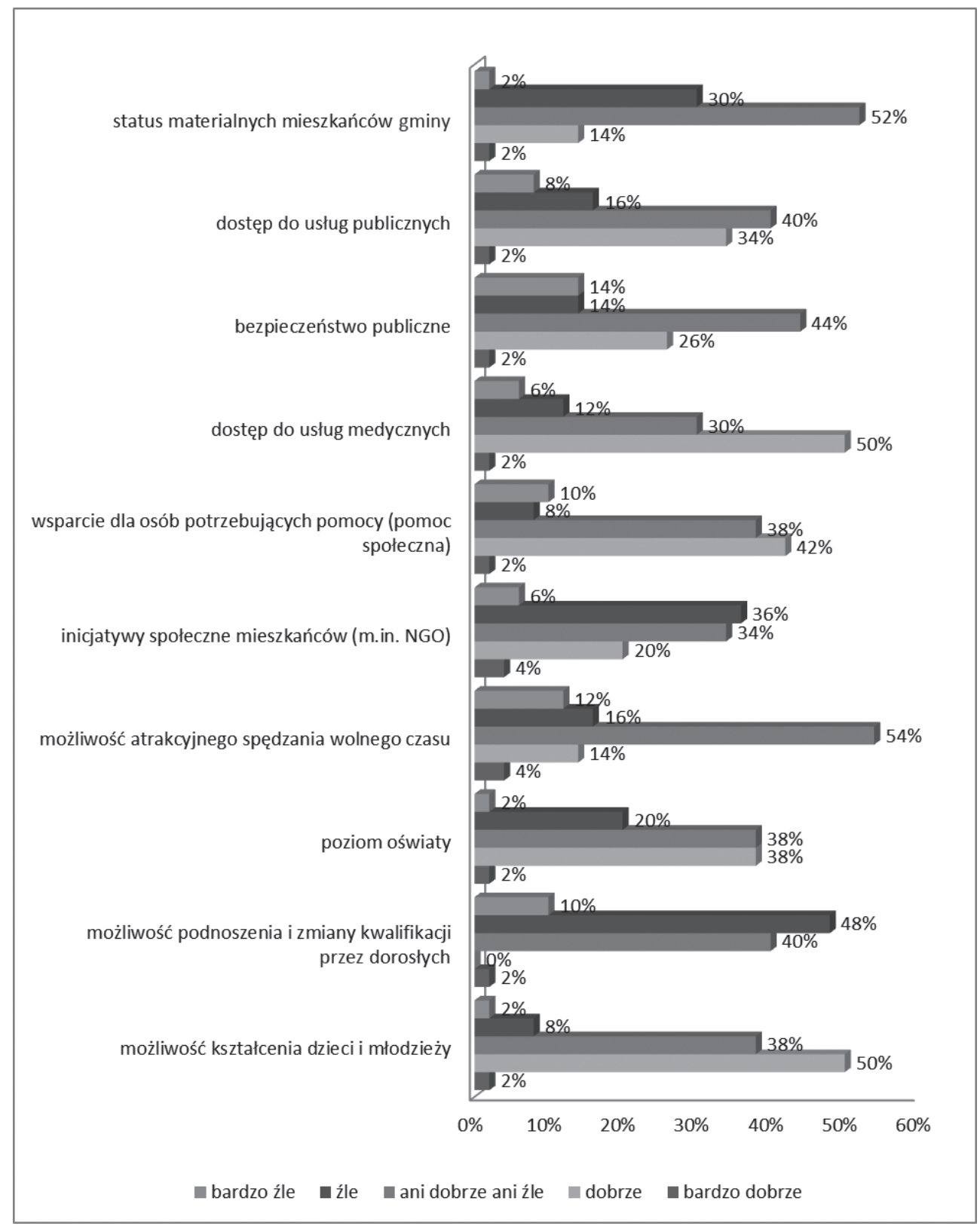

Rys. 4. Infrastruktura społeczna - ocena sfery funkcjonalnej Źródło: opracowanie własne na podstawie badań ankietowych. 


\subsection{Zarządzanie gminą}

Sfera funkcjonalna zarządzania Gminą Miejską Piechowice oceniona została bardzo dobrze. Odnotowano wysokie poziomy pozytywnych odpowiedzi zarówno w przypadku oceny poziomu obsługi klienta-mieszkańca (68\%), funkcjonowania Urzędu Miasta (60\%), jak i działań podejmowanych przez władze lokalne (46\% pozytywnych wskazań). Tak wysokie oceny w zakresie jakości zarządzania publicznego traktować można jednocześnie jako nagrodę oraz motywator na rzecz przyszłych aktywności menedżerskich.

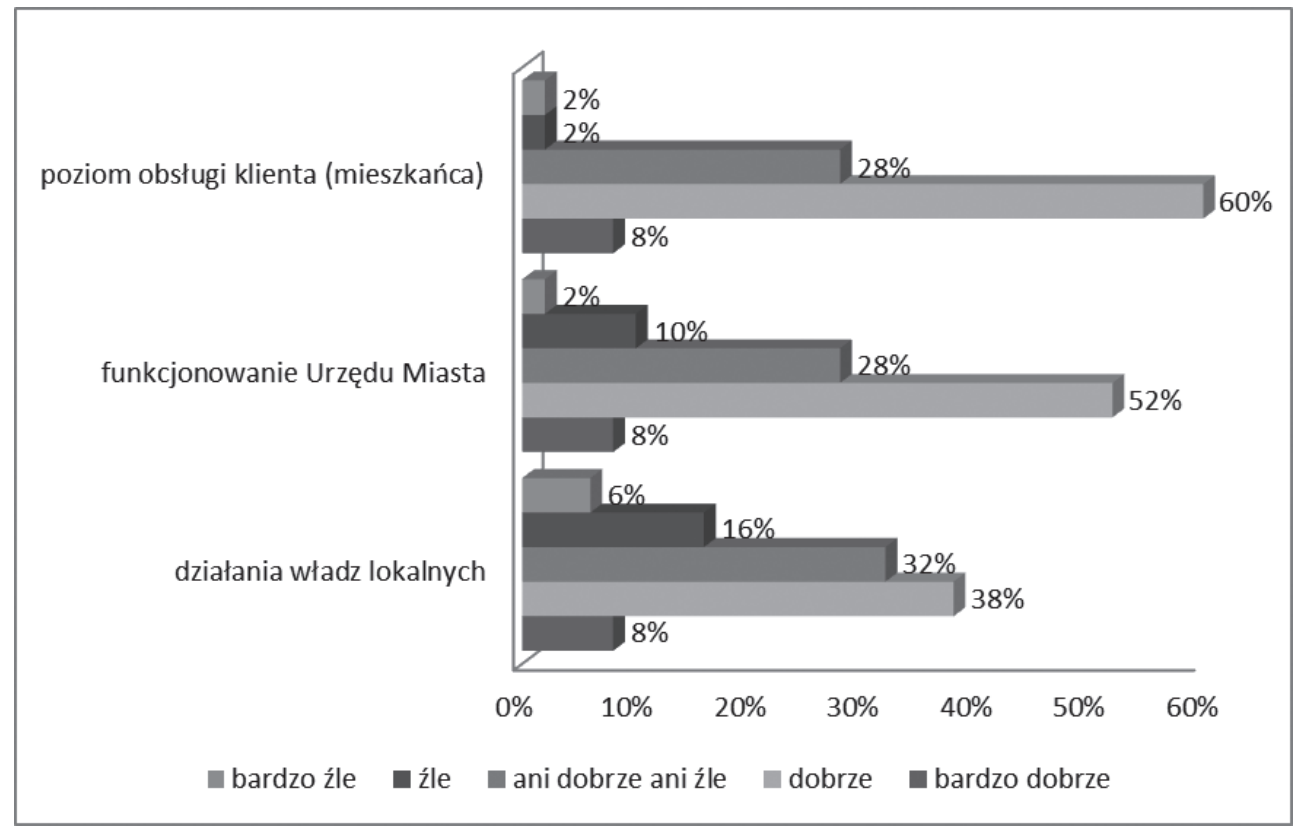

Rys. 5. Zarządzanie gminą - ocena sfery funkcjonalnej

Źródło: opracowanie własne na podstawie badań ankietowych.

\section{Podsumowanie i wnioski}

W ramach podsumowania można podjąć próbę sformułowania wybranych wniosków i rekomendacji na bazie przedstawionych wyników badań przeprowadzonych w Piechowicach.

- W ramach realizowanych i planowanych działań rozwojowych władze lokalne powinny w szerszym zakresie korzystać z informacji pochodzących od przedstawicieli społeczności lokalnej. Wykorzystywanie w szerszym zakresie endogenicznych potencjałów społecznych pozwolić może na efektywniejsze 
prowadzenie lokalnej polityki rozwoju. Ponadto możliwe są wspólne projekty $\mathrm{z}$ organizacjami pozarządowymi, np. w obszarze dopasowywania oferty edukacyjnej do wymogów rynku pracy, przeciwdziałania procesom wykluczenia społecznego czy też projekty w ramach kompleksowych działań rewitalizacyjnych (w sferze społecznej, gospodarczej, przestrzenno-funkcjonalnej, środowiskowej oraz technicznej) [Wytyczne w zakresie... 2015].

- Implementacja projektów rozwojowych w gminie powinna być objęta kontrolą obywatelską. Wspomniana kontrola przejawia się sprawowaniem nadzoru nad funkcjonowaniem instytucji publicznych, instytucji zaufania publicznego oraz zwiększaniem ich przejrzystości i przestrzeganiem reguł dobrego rządzenia. Przyjmuje się założenie, że wprowadzenie kontroli obywatelskiej skutkować powinno wyższym poziomem zarządzania publicznego, efektywniejszą realizacją samorządowych projektów.

- Proces ewaluacji strategii rozwoju gminy, której prezentowane badania stanowią element suplementarny, powinien być prowadzony w sposób efektywny oraz cykliczny. Na bazie kolejnych raportów ewaluacyjnych będzie można stwierdzić, ze stosunkowo dużym prawdopodobieństwem, czy problemy zasygnalizowane przez społeczność lokalną zostały rozwiązane lub zminimalizowane.

- Należy podkreślić, że mieszkańcy dostrzegają stosunkowo dużo silnych stron, atutów Piechowic, wśród których wymienić można położenie gminy, walory turystyczne, stan środowiska naturalnego, możliwość zrobienia zakupów, skorzystania z niezbędnych usług, dostępność Internetu. Ponadto jednoznacznie pozytywnie oceniono możliwości kształcenia dzieci i młodzieży, dostęp do usług medycznych. Na uwagę zasługuje ogólna korzystna ocena zarządzania gminą, w tym kluczowy poziom obsługi klienta-mieszkańca.

- Wśród największych problemów, słabości mieszkańcy identyfikują czystość i porządek w mieście, trudności związane ze znalezieniem atrakcyjnej pracy, poziom bezrobocia. Na uwagę zasługują negatywnie ocenione elementy infrastruktury technicznej, ze szczególnym uwzględnieniem zasobów mieszkaniowych, gminnych zabytków [Program opieki... 2015]. Ponadto negatywnie oceniono możliwość podnoszenia i zmiany kwalifikacji przez dorosłych, inicjatywy społeczne mieszkańców.

\section{Literatura}

Klasik A., 2002, Strategie regionalne. Formułowanie i wprowadzanie w życie, Wydawnictwo Akademii Ekonomicznej, Katowice.

Koncepcja Subregionalnego Produktu Turystycznego Karkonosze i Góry Izerskie, 2008, Karkonoska Agencja Rozwoju Regionalnego, Jelenia Góra.

Program opieki nad zabytkami dla Gminy Miejskiej Piechowice 2016-2019, 2015, Urząd Miasta w Piechowicach, Piechowice.

Raszkowski A., 2010, Lokalny Program Rewitalizacji Gminy Miejskiej Piechowice na lata 2010-2013, Urząd Miasta w Piechowicach, Piechowice. 
Raszkowski A., 2014, Tożsamość terytorialna w odniesieniu do rozwoju lokalnego, [w:] Prace Naukowe Uniwersytetu Ekonomicznego, nr 332: Brol R., Sztando A., Raszkowski A. (red.), Gospodarka lokalna w teorii i praktyce, Wydawnictwo Uniwersytetu Ekonomicznego we Wrocławiu, Wrocław.

Raszkowski A., 2015, Strategia Rozwoju Gminy Miejskiej Piechowice na lata 2015-2026, Urząd Miasta w Piechowicach, Piechowice.

Strategia Rozwoju Gminy Miejskiej Piechowice na lata 2010-2015, 2010, Lubuska Organizacja Turystyczna, Piechowice.

Wytyczne $w$ zakresie rewitalizacji w programach operacyjnych na lata 2014-2020, 2015, Minister Infrastruktury i Rozwoju, Warszawa. 